\title{
Pollen morphology and exine ultrastructure of Brasiliocroton P.E. Berry \& Cordeiro (Euphorbiaceae)
}

\section{Lidian Ribeiro de Souza* (1), Francisco de Assis Ribeiro dos Santos ${ }^{1}$ (D), Daniela Santos Carneiro-Torres ${ }^{1}$ (1)}

Received: May 25, 2019

Accepted: August 1, 2019

\begin{abstract}
The present study aimed to morphologically characterize the pollen grains of species of Brasiliocroton mamoninha and B. muricatus in order to expand palynological knowledge of the group and provide additional micromorphological information useful for studies of the relationships within Crotoneae. Polleniferous material was acetolysed and described using light, scanning electron and transmission microscopy. The pollen grains of the two species of Brasiliocroton were apolar, spherical, inaperaturate and medium-sized with a Croton ornamentation pattern. The Croton pattern of $B$. mamoninha is formed by subtriangular pila, $>5$-plicate with pointed apices, while for $B$. muricatus it is formed by subcircular to circular pila, $<5$-plicate with rounded apices. Ultrastructural analysis revealed a stratified sexine in both species, whereas variation in the pattern of deposition of the foot layer allowed the species to be palynologically distinguished from each other. The composition of the Croton pattern of ornamentation, the morphology of the ultrastructure of the wall and the range of variation in the diameter of the pollen grains differed between the studied species, and thus are diagnostic characters. Pollen morphology allowed the two species of Brasiliocroton to be palynologically separated, and provided data that will be useful for taxonomically circumscribing these taxa.
\end{abstract}

Keywords: Croton pattern, Crotoneae, micromorphology, palynotaxonomy, pollen grains

\section{Introduction}

Brasiliocroton was described by Berry et al. (2005a) based on morphological and molecular data. The genus name refers to its distribution that is restricted to Brazil and close affinity with representatives of Croton. Despite its close proximity to Croton, Brasiliocroton was initially identified as belonging to Micrandra, probably due to the similar leaf blades and inflorescence form, distal position of the female flowers and disposition of the fruits on the lateral branches of the panicle (Berry et al. 2005a).

Brasiliocroton belongs to tribe Crotoneae (Berry et al. 2005b) in subfamily Crotonoideae (Wurdack et al. 2005).
Tribe Crotoneae comprises six genera (Webster 2014), of which Brasiliocroton is this most recently described (Berry et al. 2005a). The genus is sister to Croton, which is the main clade of the tribe (Berry et al. 2005b) and the second largest and most diverse genus of Euphorbiaceae (Webster 1993; Berry et al. 2005b).

Phylogenetic analyses with molecular data confirmed Brasiliocroton is the sister group of Croton (Ee et al. 2008; 2011; Riina et al. 2010; 2014; Caruzo et al. 2011). Brasiliocroton and Croton mainly differ by the anthers erect in bud in Brasiliocroton and inflexed in bud in Croton (Berry et al. 2005a). One character shared by these genera is the presence of vascularized extrafloral nectaries that are structurally similar (Vitarelli et al. 2015).

1 Programa de Pós-Graduação em Botânica, Universidade Estadual de Feira de Santana, 44031-460, Feira de Santana, BA, Brazil

* Corresponding author: lidian.bio@gmail.com 
Brasiliocroton comprises two species, Brasiliocroton mamoninha and Brasiliocroton muricatus (Riina et al. 2014), which are small- to medium-sized trees with stellate trichomes, alternate leaves with ovate or occasionally obovate blades, and flowers in panicles (Fig. 1), with numerous stamens and anthers erect in bud (Berry et al. 2005a; Riina et al. 2014). Both species are restricted to Brazil. Brasiliocroton mamoninha has a disjunct distribution in southern Bahia (in Atlantic Forest remnants), Espírito Santo and eastern Minas Gerais, and in northern Maranhão (Berry et al. 2005a). However, B. muricatus is predominant in southeastern Bahia, northeastern Minas Gerais and Espírito Santo, in Atlantic Forest vegetation (Riina et al. 2014).
The species can be separated by the color of the indumentum on the young branches and inflorescence axes, position and sex of the panicles, fusion of the sepals of the pistillate flowers, and shape, size, surface and indumentum of the fruit (Riina et al. 2014). Despite these important morphological characters, micromorphological characters (e.g., palynological) that separate the species are poorly understood. In the description of B. mamoninha, Berry et al. (2005a) characterized the pollen grains; however, nothing is known about the pollen morphology of $B$. muricatus.

Palynologically, the family Euphorbicaeae has been well investigated and studies have found great morphological diversity for the pollen of its representatives (Erdtman
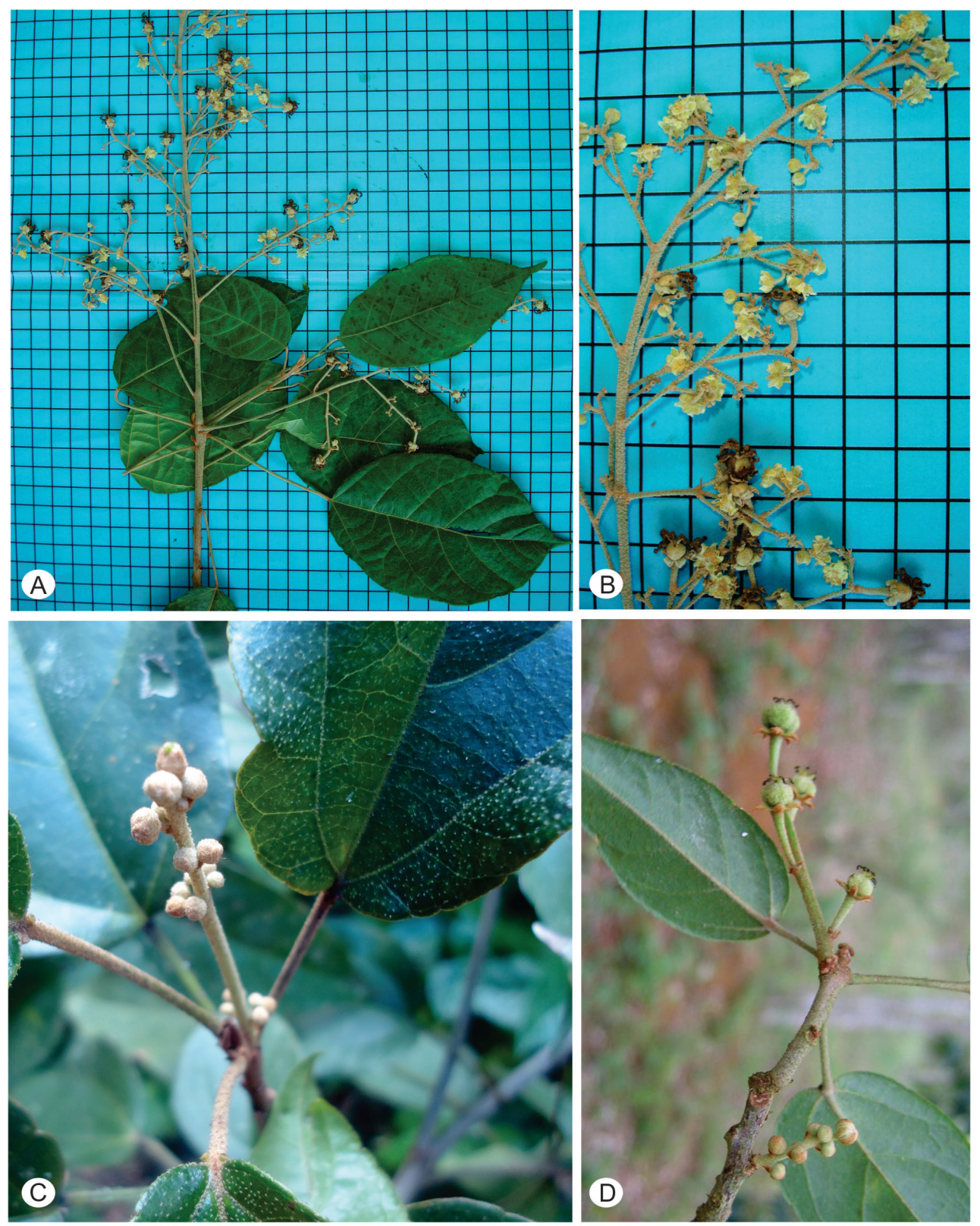

Figure 1. Illustrations of the species of Brasiliocroton (Euphorbiaceae). A-B. Brasiliocroton mamoninha: A. Flowering branch. B. Inflorescences. C-D. Brasiliocroton muricatus: C. Branch with staminate flowers in bud. D. Branch with pistillate flowers. Source (image A and B): G.S. Siqueira. 
1952; Punt 1962; Allem 1993; Nowicke 1994; LobreauCallen \& Cervera 1997; Souza et al. 2016). The eurypalynous character allows for morphopalynological inferences that can contribute to taxonomic decisions and understanding relationships between taxa (Erdtman 1952). Thus, the objective of the present work was to morphologically characterize the pollen grains of the species of Brasiliocroton to find micromorphological features that can serve as additional characters for future taxonomic studies of the genus and to better understand how Brasiliocroton is related to other genera of tribe Crotoneae.

\section{Materials and methods}

The botanical material (flower buds) of Brasiliocroton mamoninha P.E.Berry \& Cordeiro and B. muricatus Riina \& Cordeiro (Tab. 1) was collected from specimens deposited in the CEPEC (Herbário do Centro de Pesquisa do Cacau) and HUEFS (Herbário da Universidade Estadual de Feira de Santana) herbaria.

\section{Pollen treatment}

Acetolysis (Erdtman 1960) and light microscopy (LM) were used to make observations. Pollen grains removed from flower buds were submitted to an acetolysis mixture and, after the process, were mounted between slides and coverslips with glycerinated gelatin and sealed with molten paraffin. Of the five slides made, one was mounted with glycerinated gelatin stained with safranin to better visualize the morphological characters of the pollen. The slides were labeled and deposited in the palynology collection of the Laboratório de Micromorfologia Vegetal at the Universidade Estadual de Feira de Santana.

To analyze the pollen surface using scanning electron microscopy (SEM) was followed by the protocol used by Souza et al. (2017). The electromicrographs were made at the Centro de Microscopia Eletrônica of the Universidade Estadual de Santa Cruz (UESC), using a Quanta 250 microscope (FEI Company), and the Plataforma de Microscopia Eletrônica at the Centro de Pesquisas Gonçalo Moniz (FIOCRUZ), using at JEOL 6390LV microscope.

For the detailed analysis of the structure of the exine using transmission electron microscopy (TEM), non- acetolyzed polleniferous material (anthers) was fixed in glutaraldehyde ( $4 \%$ ) and a $0.2 \mathrm{M}$ sodium cacodylate buffer solution $(2 \mathrm{~h})$. Subsequently, the material was washed in a buffer solution of sodium cacodylate and post-fixed in $1 \%$ osmium tetroxide $(\mathrm{OsO} 4)+1.6 \%$ potassium ferricyanide $+5 \mathrm{mM}$ calcium chloride in a sodium cacodylate buffer for one hour and thirty minutes. The anthers were washed again and then dehydrated in an increasing acetone series (30, 50, 70, 90 and $100 \%)$.

The last wash was made with absolute super dry acetone and repeated three times. The samples were embedded in polybed resin at room temperature and the blocks were thinly sliced $(70 \mathrm{~nm})$ with an ultramicrotome. The slices where stained with $7 \%$ uranyl acetate and lead citrate and observed with a Jeol JEM 1230 transmission electron microscope.

The TEM analysis was conducted at FIOCRUZ.

\section{Pollen description}

Only one diameter of the pollen grains was measured because they are apolar. To standardize the sample, measurements were made from 25 randomly selected pollen grains from at least five slides. The morphometric parameters, such as sexine and nexine thickness, diameter of the rosettes, diameter of the pila and diameter of the central space of the rosette, were measured as illustrated by Souza et al. (2016); ten randomly selected pollen grains were measured.

The quantitative results were statistically analyzed by calculating the arithmetic mean, standard deviation of the sample, coefficient of variability, confidence interval at $95 \%$ and variation range for the measurements with a sample size of 25. For the remaining measurements with a sample size of ten, only the arithmetic mean was calculated.

The pollen morphology characters were illustrated with photomicrographs and electromicrographs (scanning and transmission). The following features of the pollen were described: size, shape, polarity, apertures, ornamentation and exine sculpture. For this, the palynological nomenclature of Punt et al. (2007) and Hesse (2009) was adopted; the latter was used to help describe the exine ultrastructure.

Table 1. Material examined of the species of Brasiliocroton (Euphorbiaceae) used in the morphological analysis of the pollen grains.

\begin{tabular}{|c|c|c|}
\hline \multicolumn{1}{|c|}{ Species } & Locality & Voucher \\
\hline Brasiliocroton mamoninha P.E.Berry \& Cordeiro & Bahia, Mucurí & Santos 1543 \\
\hline Brasiliocroton mamoninha P.E.Berry \& Cordeiro & Bahia, Alcobaça & Santos 2114 \\
\hline Brasiliocroton mamoninha P.E.Berry \& Cordeiro & Espírito Santo & Árbocz 1390 \\
\hline Brasiliocroton muricatus Riina \& Cordeiro & Bahia, Cruz das Almas & Carneiro-Torres 1233 \\
\hline Brasiliocroton muricatus Riina \& Cordeiro & Bahia, Jequié & Carneiro-Torres 1004 \\
\hline Brasiliocroton muricatus Riina \& Cordeiro & Bahia, Jequié & Thomas 13584 \\
\hline Brasiliocroton muricatus Riina \& Cordeiro & Bahia, Itatim & Carneiro-Torres 1005 \\
\hline Brasiliocroton muricatus Riina \& Cordeiro & Bahia, Valença, & França s.n. \\
\hline
\end{tabular}




\section{Results}

The pollen studied could be differentiated between the two species. Characteristics, such as variation in the size of the pollen grains associated with differences in the composition of the exine ornamentation of the Croton pattern and morphology of the wall ultrastructure (Fig. 2), allowed the species to be palynologically separated. The morphological characteristics are summarized in Tables 2 and 3 and the morphometric data is summarized in Table 4. The statistical analyses are illustrated in Figures 3 and 4 .

In general, the pollen grains of Brasiliocroton is mediumsized, apolar, spherical, inaperturate and has a Croton pattern exine, with a thicker sexine than nexine, and a wall ultrastructure with columellae and notably discontinuous tectum.

Brasiliocroton mamoninha P.E. Berry \& Cordeiro (Fig. 2A-E).

Table 2. Morphological characters of the pollen grains of the species of Brasiliocroton (Euphorbiaceae). M= medium-sized, $\mathrm{S}=$ spheroidal, $\mathrm{Se}=$ sexine, $\mathrm{Ne}=$ nexine.

\begin{tabular}{|c|c|c|}
\hline & Brasilocroton mamoninha & Brasilocroton muricatus \\
\hline Size & $\mathrm{M}$ & $\mathrm{M}$ \\
\hline Shape & S & S \\
\hline Apertural type & Inaperturate & Inaperturate \\
\hline \multicolumn{3}{|c|}{ Composition exine Croton pattern } \\
\hline Pila shape & Subtriangular & Subcircular to circular \\
\hline Pila number & $5-7-(8)$ & $5-7$ \\
\hline Pila ornamentation & $>5$-Plicate & $<5$-Plicate \\
\hline Pila apex & Pointed & Rounded \\
\hline Space inside to pilum rosettes & Well delimited & Well delimited to reduced \\
\hline Free sexine elements inside of the lumen rosettes & Clavae, bacula and granula & Clavae, bacula and granula, \\
\hline Free sexine elements more frequent inside of the lumen rosettes & Clavae & Granula \\
\hline Intensity of free sexine elements inside to pilum rosettes & Sparsely distributed & Densely distributed \\
\hline Sexina/nexina & $\mathrm{Se}>\mathrm{Ne}$ & $\mathrm{Se}>\mathrm{Ne}$ \\
\hline
\end{tabular}

Table 3. Morphological characters of the exine ultrastructure of pollen grains of the species of Brasiliocroton (Euphorbiaceae).

\begin{tabular}{|c|c|c|}
\hline & Brasilocroton mamoninha & Brasilocroton muricatus \\
\hline Thickness & NEXINE & Thin \\
\hline Texture & Thick & Compact \\
\hline Endexine & Spongy & compact \\
\hline Foot layer & granular & Short, thick and discontinuous \\
\hline Columella & SEXINE & Spaced \\
\hline Distribution & Short, thick and discontinuous & + \\
\hline Fusion & Spaced & Thin and discontinuous \\
\hline Semitectum & - & Thick, large and with rounded apex \\
\hline Pilum & Thin and discontinuous & Without uniformity \\
\hline Distribution & Thick, large and with pointed apex & + \\
\hline
\end{tabular}

Table 4. Morphometric characters of the pollen grains of the species of Brasiliocroton studied. $\mathrm{D}=$ pollen grain diameter, Fv= range variation, $\mathrm{DR}=$ diameter of the rosettes, $\mathrm{DP} i=$ diameter of the pila, $\mathrm{DCSR}=$ diameter of the central space of the rosettes, Sex= Sexine, Nex $=$ Nexine, Exi $=$ exine; measurements in $\mu \mathrm{m}$ and indices in absolute numbers.

\begin{tabular}{|c|c|c|c|c|c|c|c|c|}
\hline \multirow{2}{*}{ Species } & \multicolumn{2}{|c|}{ D } & \multirow{2}{*}{ DR } & \multirow{2}{*}{ DPi } & \multirow{2}{*}{ DCSR } & \multirow{2}{*}{ Sex } & \multirow{2}{*}{ Nex } & \multirow{2}{*}{ Exi } \\
\hline & $x^{-} \pm 5 x^{-}$ & Fv & & & & & & \\
\hline \multicolumn{9}{|l|}{ Brasiliocroton mamoninha P.E.Berry \& Cordeiro } \\
\hline T.S. Santos 1543 (CEPEC) & $32.3 \pm 0.12$ & $30.0-32.5$ & 3.1 & 1.0 & 1.0 & 2.0 & 1.0 & 3,0 \\
\hline T.S. Santos 2114 (CEPEC) & $32.5 \pm 0.12$ & $30.0-32.5$ & 3.1 & 1.0 & 1.0 & 2.1 & 1.0 & 3.1 \\
\hline G.F. Árbocz 1390 (HUEFS) & $30.0 \pm 0.11$ & $27.5-32.5$ & 2.4 & 0.5 & 0.8 & 1.9 & 1.0 & 2.9 \\
\hline \multicolumn{9}{|l|}{ Brasiliocroton muricatus Riina \& Cordeiro } \\
\hline D.S. Carneiro-Torres 1004 (HUEFS) & $39.4 \pm 0.16$ & $35.0-42.5$ & 3.0 & 0.6 & 1.0 & 2.2 & 1.0 & 3.2 \\
\hline D.S. Carneiro-Torres 1005 (HUEFS) & $36.7 \pm 0.20$ & $32.5-40.0$ & 3.0 & 1.0 & 1.0 & 2.0 & 1.0 & 3.0 \\
\hline D.S. Carneiro-Torres 1233 et al. (HUEFS) & $35.4 \pm 0.17$ & $32.5-37.5$ & 3.0 & 1.0 & 1.0 & 1.9 & 1.0 & 2.9 \\
\hline W.W. Thomas 13584 (CEPEC) & $34.6 \pm 0.16$ & $32.5-37.5$ & 2.5 & 0.7 & 1.0 & 1.6 & 1.0 & 2.6 \\
\hline S.O. França s/n (CEPEC) & $38.5 \pm 0.13$ & $37.5-42.5$ & 3.0 & 1.0 & 1.0 & 1.8 & 1.0 & 2.8 \\
\hline
\end{tabular}




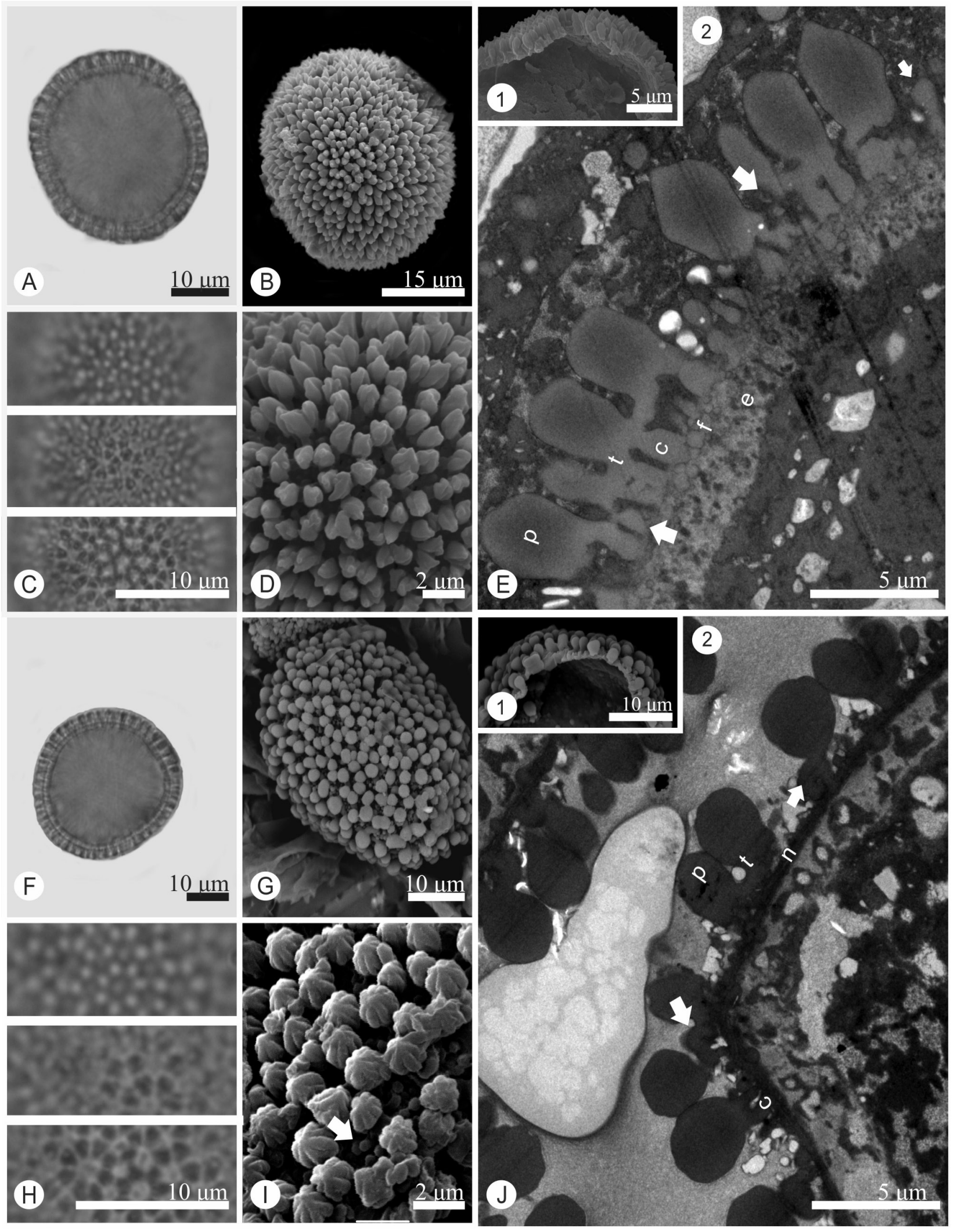

Figure 2. Pollen grains of the species of Brasiliocroton (Euphorbiaceae). A-E. Brasiliocroton mamoninha: A. Optical section. B. Surface (SEM). C. L.O. D. Detail of the surface (SEM). E. (1) Detail of the exine of a fragmented pollen grain (SEM), (2) Wall structure, showing the presence of clavae (arrow). F-J. Brasiliocroton muricatus: F. Optical section. G. Surface (SEM). H. L.O. I. Detail of the surface (SEM), showing the presence of granules (arrow). J. (1) Detail of the exine of a fragmented pollen grain (SEM), (2) Wall structure, showing columellae and discontinuous tectum (arrow). $\mathrm{P}=$ pilum, $\mathrm{T}=$ tectum, $\mathrm{C}=$ columella, $\mathrm{F}=$ foot layer, $\mathrm{E}=$ endexine, $\mathrm{N}=$ nexine. 


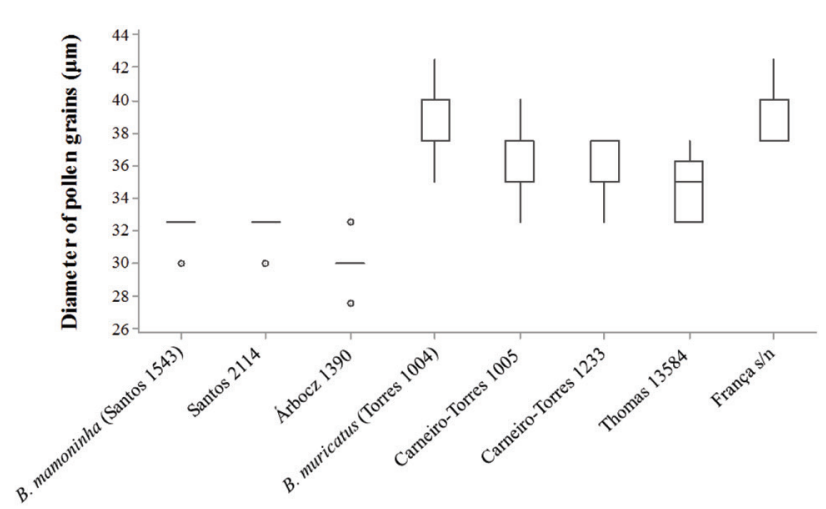

Figure 3. Boxplot graph of the distribution of the variable diameter of pollen grains of Brasiliocroton (Euphorbiaceae). The horizontal bar inside the rectangle is the median, the rectangle shows $50 \%$ of interquartile, the ends show the amplitude variation and the black circles correspond to the outlier.

Pollen grains medium-sized, with a mean diameter of $31.6 \mu \mathrm{m}$, rosettes formed by $5-7(8)$ subtriangular pila with a plicate surface (head pilum foldings $>5$ ) and pointed apex (Fig. 2D-E), rosettes with well-delimited central space, with clavae, bacula and granules (less frequent) sparsely distributed in the lumen (Fig. 2C, E).

The study of the wall ultrastructure of the pollen grains revealed a sexine formed by a supratectal ectexine and stratified infratectum (columellate). The sexine is composed of a supratectum that has thick and large pila. The pila have predominantly pointed apices and are nonuniformly distributed, leaving heterogeneous spaces among themselves (Fig. 2E). The semitectum is relatively thin and discontinuous; in the discontinuous regions there are small clavae, bacula and, less frequently, granules. The columellae are short, thick, and widely spaced and discontinuous (Fig. 2E).

The foot layer is continuous, irregularly thick, and composed of dense granules of different shapes and sizes in a sequence of one to four levels (Fig. 2E). The intine is relatively thick. The endexine is difficult to be discernible.

Brasiliocroton muricatus Riina \& Cordeiro (Fig. 2F-J).

Pollen grains medium-sized, with a mean diameter of $36.9 \mu \mathrm{m}$, rosettes formed by $5-7$ subcircular to circular

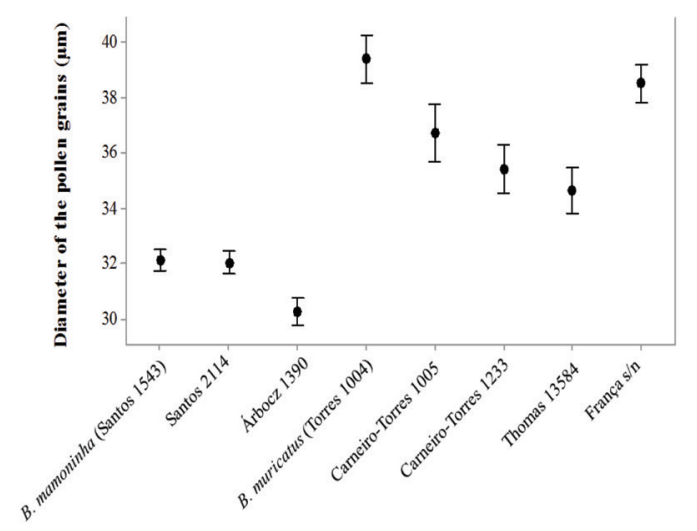

Figure 4. Graphic representation of $95 \%$ confidence interval for the mean diameter of the pollen grains of the Brasiliocroton species. Circles represent the means and vertical lines represent the range of variation. ${ }^{*}$ Individual standard deviations were used to calculate the intervals.

pila with a plicate surface (head pilum foldings $<5$ ) and rounded apex (Fig. 2I-J), rosettes with well-delimited to reduced central space, with clavae, bacula and granules (more frequent) densely distributed in the lumen.

In this species, the pollen grains have an exine composed of simple and compound elements in the infratectum. The sexine is formed by a supratectum composed of large, thick pila with notably rounded apices (Fig. 2J). Sometimes the base of the pilum narrows, making it look morphologically similar to a gemma. The distribution of the pila is heterogeneous. Sometimes the spacing is very reduced and, occasionally, the apices of the pila are united (Fig. 2J). The semitectum is very discontinuous and not apparent. In the discontinuous regions there are predominantly granules dispersed under the basal layer; clavae and bacula were less frequent. The columellae are short, thick, sparsely distributed, very discontinuous and sometimes fused (Fig. 2J).

The foot layer is continuous, compact and formed by two layers, which have the same thickness and can be differentiated (Fig. 2J). After this layer there are the elements that compose the intine that will be more defined at maturity of the pollen grain.

\section{Pollen identification key of the species of Brasiliocroton}

1 Pila $>$ 5-plicate, subtriangular with pointed apex, sexine elements (clavae, bacula and granules) inside to rosettes sparsely distributed, most frequently clavae..... B. mamoninha 1' Pila <5-plicate, subcircular to circular with rounded apex, sexine elements (clavae, bacula and granules) inside to rosettes densely distributed, most frequently granules B. muricatus

\section{Discussion}

The pollen morphology of Brasiliocroton includes characteristics that correspond to the general pattern in Crotoneae, mainly for polarity, ornamentation pattern of the exine and aperture type (Nowicke 1994; Souza et al. 2016). Nowicke (1994) affirmed that the presence of inaperaturate pollen grains is restricted to eudicotyledons, predominant in Crotonoideae, rare in other taxa of Euphorbiaceae, and could support the monophylly of inaperaturate tribes of the family. Years later, Wurdack et al. (2005), in a molecular 
phylogenetic study of uniovulate Euphorbiaceae, noted that inaperaturate pollen is a synapomorphy of the "inaperturate crotonoids" clade, one of the four lineages of Crotonoideae, which includes Crotoneae.

The two species of Brasiliocroton have medium-sized pollen; however, two ranges of variation were observed. Brasiliocroton mamoninha had a pollen grain diameter that varied from 27.5 to $32.5 \mu \mathrm{m}$, while the diameter was relatively larger for B. muricatus and ranged 32.5 to 42.5 $\mu \mathrm{m}$; the range reached $42.5 \mu \mathrm{m}$ in two of the five specimens analyzed. Based on this, we realized that even for species belonging to the same class size, variation in pollen grain diameter can be useful when differentiating the species.

Berry et al. (2005a) found a diameter of $48.6 \mu \mathrm{m}$ for pollen grains of $B$. mamoninha, which is a considerably higher value compared to what the present study found for the same species. This variation could be because the authors measured non-acetolyzed material and the presence of cellular content may have considerably influenced the diameter of the pollen.

In relation to the quantitative data of the composition of the Croton pattern (diameter of the rosettes, diameter of the pila, diameter of the central space of the rosette), no significant variation was observed between the species investigated. The mean diameter of the rosettes was $2.8 \mu \mathrm{m}$ and the mean diameter of the pila and central space of the rosettes was $0.85 \mu \mathrm{m}$. Lima et al. (2007) examined the pollen of 21 Croton species and did not find a correlation between pollen grain diameter and diameter of the ornamentation unit. This is because species that have larger pollen grains do not necessarily have larger rosettes and the authors concluded that the characteristic was continuous resulting in no distinct groups, which was also observed in the present study.

The subunits that compose the rosettes of the Croton pattern have a plicate surface characterized by the presence of folds in the wall of the subunit. Berry et al. (2005a) characterized the subunits of $B$. mamoninha as having a striate surface with attenuate apices and noted their distal portion was thinner, a character that was also observed in the present study and can be used to palynologically distinguish the species. However, for the ornamentation of the pila, our results differ from Berry et al. (2005a).

For Croton, the sister group, pila with psilate (Carreira et al. 1996), striate (Nowicke 1994; Carreira et al. 1996; Lima et al. 2007) and plicate (Souza et al. 2016) surfaces have been reported. Further, the apices can be rounded (Nowicke 1994) or, less frequently, pointed (Carreira et al. 1996). The pilum morphology of B. mamoninha is more similar to that of Sagotia (Nowicke 1994), an Amazonian genus restricted to Brazil that is sister to the remaining genera of Crotoneae (Berry et al. 2005b), since pila with pointed apices are uncommon in Croton; for Croton, this morphology has only been described by Carreira et al. (1996) for the few lianescent species.

Pilum shape is also a good characteristic to differentiate the studied species. In B. mamoninha the pila were mostly subtriangular and in B. muricatus they were subcircular to circular. Souza et al. (2016) studied the pollen morphology of four genera of Crotonoideae and also observed variations in pilum shape. Further, when using this character, the authors could group the representatives of the genus Manihot since they all had notably triangular pila.

Another characteristic that helped palynologically differentiate the species of Brasiliocroton was the morphology of the pilum apex, since the apex was pointed in B. mamoninha and rounded in B. muricatus. A pointed apex was also observed by Berry et al. (2005a) for the pila of B. mamoninha. Nowicke (1994) noted the presence of rounded, flat and pointed apices, which were sometimes echinate, for many representatives of Crotonoideae.

Brasiliocroton mamoninha and B. muricatus had clavae, bacula and granules in the lumen of the rosettes and the frequency of the granules varied between the species. In $B$. muricatus, the granules were more predominant compared the other elements, a characteristic that was not observed in B. mamoninha. Nowicke (1994) and Lima et al. (2007) cited the presence of granules in the lumen of the rosettes for species of Croton. For Souza et al. (2016), this character was diagnostically valuable and was used to group the genera they studied. They observed the presence of elements of the sexine in the lumen of the rosettes in Croton and Jatropha; however, for Cnidoscolus and Manihot this character was not observed. The proximity of the genera found by these authors corroborates the phylogeny proposed by Tokuoka (2007), where Cnidoscolus is sister to Manihot. The presence of elements of the sexine in the lumen of the rosettes was not reported by Berry et al. (2005a).

The ultrastructure of the wall of the pollen grains also provides good micromorphological information because its composition is very different for the species investigated. Brasiliocroton mamoninha has a spongy foot layer formed by minute structures (of various formats) deposited in a sequence of one to four levels with an irregular thickness, while the foot layer of B. muricatus is formed by two compact, thin layers. From the images of the ultrastructure it was also possible to confirm the differences in the morphological conformations of the apices of the pila that make up the Croton pattern.

In general, the ultrastructure of the exine of the species studied has short, thick, very discontinuous columellae that caused the formation of a discontinuous and sometimes non-apparent tectum. This conformation is a characteristic that the species of Brasiliocroton have in common. This is the first time that information about the ultrastructure of the exine of Brasiliocroton has been published.

The pollinic characteristics observed in Brasiliocroton correlated well with the macromorphological characters, reported by Riina et al. (2014), used to distinguish the species of the genus. The authors used characters such as color of the indumentum on young branches and inflorescence axes, position and sex of the panicles, fusion of the sepals of the pistillate flowers and shape, size, surface and indumentum of the fruits as diagnostic characters. 
The species with the Brasiliocroton mamoninha pollen type has whitish to ochraceous indumentum on the inflorescence axes and young branches, bisexual, terminal inflorescences, pistillate flowers with connate sepals, and smooth, sphericaltrigonous fruits with dendritic, ochraceous to brown trichomes. However, the species with the Brasiliocroton muricatus pollen type has ferruginous indumentum on the inflorescence axes and young branches, unisexual (rarely bisexual), axillary inflorescences, pistillate flowers with distinct sepals and muricate, spherical, slightly flattened fruits with stellate, whitish trichomes. Thus, the palynological data increases what is known about the morphology and helps in the identification of the species of Brasiliocroton.

\section{Conclusions}

The palynological characters of Brasiliocroton correspond to the general pattern found in the representatives of tribe Crotoneae, mainly the polarity, aperture type and ornamentation pattern of the exine.

The morphology of the pollen allowed the species of Brasiliocroton to be palynologically separated and contributes to what is known about and helps in the taxonomic circumscription of these taxa. The variation in the diameter of the pollen grains associated with the composition of the ornamentation of the Croton pattern (mainly shape, number of plicae and morphology of the pilum apex) and morphology of the ultrastructure of the wall were diagnostic characters that palynologically separated the studied species.

The data also demonstrate that the micromorphological information correlates well with the macromorphological characters of the group, allowing us to affirm that the results of the present work increase what is known about the palynology of Brasiliocroton and pollen morphology of B. muricatus and can be used in future studies to better understand the evolutionary relationships within tribe Crotoneae.

\section{Acknowledgements}

We thank the FAPESB for the doctorate scholarship awarded to the first author, the CNPq for the scientific productivity research grant awarded to FARS, the curators at the herbaria HUEFS and CEPEC, the CME-UESC and FIOCRUZ for allowing us to conduct the electron and transmission microscopy analyses, Bahia Flora project for allowing resources for translation, Dra. Inês Cordeiro and Geovane Siqueira for granting the images of $B$. mamoninha and Dra. Marta Morbelli by contributions in the ultrastructure descriptions.

\section{References}

Allem AC. 1993. Palynotaxonomy of Manihot Section Quinquelobae (Euphorbiaceae). Revista Brasileira de Biologia 53: 71-79.
Berry PE, Cordeiro I, Wiedenhoeft AC, Vitorino-Cruz MA, Lima LR, Manos PS. 2005a. Brasiliocroton, a new crotonoid genus of Euphorbiaceae s.s. from Eastern Brazil. Systematic Botany 30: 357-365.

Berry PE, Hipp AL, Wurdack KJ, Ee BW, Riina R. 2005b. Molecular phylogenetics of the giant genus Croton and tribe Crotoneae (Euphorbiaceae sensu stricto) using ITS and TRNL-TRNF DNA sequence data. American Journal of Botany 92: 1520-1534.

Carreira LMM, Secco R, Barth OM. 1996. Pollen morphology of the lianescent species of the genus Croton (Euphorbiaceae). Grana 35: 74-78.

Caruzo MBR, Ee BW, Cordeiro I, Berry PE, Riina R. 2011. Molecular phylogenetics and character evolution of the "sacaca" clade: Novel relationships of Croton section Cleodora (Euphorbiaceae). Molecular Phylogenetics and Evolution 60: 193-206.

Ee BW, Berry PE, Riina R, Gutierrez Amaro JE. 2008. Molecular phylogenetics and biogeography of the Caribbeancentered Croton subgenus Moacroton (Euphorbiaceae s. s.). Botanical Review 74: 132-165.

Ee BW, Riina R, Berry PE. 2011. A revised synopsis and molecular phylogeny of the New World sections of Croton (Euphorbiaceae). Taxon 60: 791-823.

Erdtman G. 1952. Pollen morphology and plant taxonomy. Angiosperms. An introduction to palynology. Stockholm, Almqvist \& Wiksell.

Erdtman G. 1960. The acetolysis method. A revised description. Svensk Botanisk Tidskrift 54: 561-564.

Hesse M, Halbritte H, Zetter R, et al. 2009. Pollen terminology. An illustrated handbook. New York, Springer.

Lima LR, Cruz-Barros MAV, Pirani JR, Corrêa MAS. 2007. Pollen morphology of Croton sect. Lamprocroton (Müll.Arg.) Pax (Euphorbiaceae) and its taxonomic implications. Nordic Journal of Botany 25: 206-216.

Lobreau-Callen D, Cervera MS. 1997. Le pollen des Crotonoideae apétales (Euphorbiaceae): ultrastructure de l'exine. Review of Paleobotany and Palynology 98: 257-291.

Nowicke JW. 1994. A Palynological Study of Crotonoideae (Euphorbiaceae). Annals of the Missouri Botanical Garden 81: 245-269.

Punt W. 1962. Pollen morphology of the Euphorbiaceae with special reference to taxonomy. Wentia 7: 1-116.

Punt W, Hoen PP, Blackmore S, Nilsson S, Thomas A. 2007. Glossary of pollen and spore terminology. Review of Paleobotany and Palynology 143: 1-81.

Riina R, Ee BW, Wiedenhoeft AC, Cardozo A, Berry PE. 2010. Sectional rearrangement of arborescent clades of Croton (Euphorbiaceae) in South America: evolution of arillate seeds and a new species, Croton domatifer. Taxon 59: 1147-1160.

Riina R, Carneiro-Torres DS, Peirson JA, Berry PE, Cordeiro I. 2014. Further Support for the Crotoneae Phylogeny: A New Species of Brasiliocroton (Euphorbiaceae) Based on Morphological, Geographical, and Molecular Evidence. Systematic Botany 39: 227-234.

Souza LR, Carneiro-Torres DS, Saba MD, Santos FAR. 2016. Pollen morphology of Crotonoideae (Euphorbiaceae) from Seasonally Dry Tropical Forests, Northeastern Brazil. Plant Systematics and Evolution 302: 795-817.

Souza LR, Carneiro-Torres DS, Saba MD, Santos FAR. 2017. Pollen morphology of the Acalyphoideae and Euphorbioideae (Euphorbiaceae) of the Caatinga ecoregion in Brazil. Plant Systematics and Evolution 303: 1161-1180.

Tokuoka T. 2007. Molecular phylogenetics analisys of Euphorbiaceae sensu strito base on plastid and nuclear DNA sequences, ovule, and seed character evolution. Journal of Plant Research 120: 511-522.

Vitarelli NC, Riina R, Caruzo MBR, Cordeiro I, Fuertes-Aguilar J, Meira RMSA. 2015. Foliar secretory structures in Crotoneae (Euphorbiaceae): diversity, anatomy, and evolutionary significance. American Journal of Botany 102: 833-847.

Webster GL. 1993. A provisional synopsis of the sections of the genus Croton (Euphorbiaceae). Taxon 42: 793-823.

Webster GL. 2014. Euphorbiaceae. In: Kubitzki K. (ed.) Flowering Plants: Eudicots, the families and genera of vascular plants. Berlin, SpringerVerlag: p. 51-216.

Wurdack KJ, Hoffmann P, Chase MW. 2005. Molecular phylogenetic analysis of uniovulate Euphorbiaceae (Euphorbiaceae sensu stricto) using plastid $\mathrm{rbcL}$ and trnLF DNA sequences. American Journal of Botany 92: 1397-1420. 